\title{
DIAGNOSTIC CENTRAL OBESITY INDEXES CUT - OFF POINT VALUES DETERMINED WITH DUAL-ENERGY X-RAY ABSORPTIOMETRY IN CUSHING'S AND OBESE WOMEN
}

\author{
Slavica Shubeska Stratrova ${ }^{1}$, Sasha Jovanovska Mishevska ${ }^{1}$, Iskra Bitoska ${ }^{1}$, Irena Kafedziska ${ }^{2}$
}

\author{
${ }^{1}$ University Clinic of Endocrinology, Diabetes and Metabolic Disorders, Faculty of Medicine, University Ss Cyril and Methodi- \\ us, Skopje, R. N. Macedonia \\ ${ }^{2}$ University Clinic of Rheumatology, Faculty of Medicine, University Ss Cyril and Methodius, Skopje, R. N. Macedonia
}

Corresponding author: Prof. d-r Slavica Shubeska Stratrova, MD, PhD; University Clinic of Endocrinology, Diabetes and Metabolic Disorders, Mother Theresa St. 17, 1000 Skopje, R. N. Macedonia, E-mail: slavass02@, yahoo.com

\section{ABSTRACT}

Aim: The aim of this study was to develop quantiative criteria for defining visceral obesity and to establish dual-energy X-ray absorptiometric (DXA) diagnostic cut-off points (CP) for normal and abnormal values of the central obesity indexes (COI) that best differentiate extreme visceral obesity in Cushing's syndrome (CS) from non CS obese and non obese women.

Material and Methods: $\mathrm{COI}_{1-4}$ values calculated as a ratio of android to gynoid tissue mass, fat mass and their $\%$ were determined in 4 groups, each consisting of 18 women: $1^{\text {st }}$ group of CS, $2^{\text {nd }}$ group of obese women $\left(\mathrm{O}_{1}\right)$ not different according to their age and BMI from CS, $3^{\text {rd }}$ group of obese women $\left(\mathrm{O}_{2}\right)$ with BMI of $35 \pm 1.2 \mathrm{~kg}$ and $4^{\text {th }}$ group of non obese healthy women (C) with normal BMI. Diagnostic accuracy (DG) of CP values of $\mathrm{COI}_{1 \mathrm{~m}-4 \mathrm{~m}}$ indexes of abdominal obesity and $\mathrm{CP}$ values of $\mathrm{COI}_{1 \mathrm{n}-4 \mathrm{n}}$ indexes of normal body fat distribution (BFD) was determined.

Results: $\mathrm{COI}_{1-4}$ indexes values were highly significantly different among the 4 examined groups and were significantly highest in CS patients and lowest in group $\mathrm{C}(\mathrm{p}<0.0001) . \mathrm{COI}_{1 \mathrm{~m}-4 \mathrm{~m}} \mathrm{CP}$ values differentiated extreme visceral, abdominal obesity in $\mathrm{CS}$ with highest $\mathrm{DG}$ as well as $\mathrm{COI} \mathrm{I}_{1 \mathrm{n}-4 \mathrm{~m}} \mathrm{CP}$ values differentiated normal BFD in group C. $\mathrm{COI}_{1 \mathrm{~m}} \mathrm{CP}$ of 0.55 best differentiated $\mathrm{CS}$ from $\mathrm{O}_{1}$ for DG of $100 \%$. $^{1 \mathrm{n}-4 \mathrm{n}}{ }_{2 \mathrm{n}}$ of 0.38 best differentiated $\mathrm{C}$ from $\mathrm{CS}$ and $\mathrm{O}_{2}$ for highest $\mathrm{DG}$ of $100 \%$ compared to $\mathrm{O}_{1}$ because of the significantly higher BMI and $\mathrm{COI}_{1 \mathrm{n}-4 \mathrm{n}}$ values in $\mathrm{O}_{2}$ that were associated with more pronounced abdominal obesity and highly significantly positive correlation with BMI.

Conclusions: DXA cut-off point values of indexes $\mathrm{COI}_{1 \mathrm{~m}-4 \mathrm{~m}}$ and $\mathrm{COI}_{1 \mathrm{n}-4 \mathrm{n}}$ were established as diagnostic indexes and criteria useful in discovering extreme abdominal and normal BFD. $\mathrm{COI}_{1 \mathrm{~m}} \mathrm{CP}$ value of 0.55 was discovered as a diagnostic criterion of extreme abdominal obesity and $\mathrm{COI}_{2 \mathrm{n}}$ of 0.38 as a diagnostic criterion of normal BFD that excluded abdominal obesity. The other indexes $\mathrm{COI}_{1 \mathrm{~m}-4 \mathrm{~m}}$ and $\mathrm{COI}_{1 \mathrm{n}-4 \mathrm{n}} \mathrm{CP}$ values had also high DG in discovering abdominal and normal body fat distribution.

Keywords: DXA, abdominal obesity, central obesity indexes, cut-off point values 


\section{INTRODUCTION}

Metabolic syndrome (MS) is defined as a complex of interrelated risk factors, including obesity (particularly central obesity), impaired fasting glucose, hypertension, elevated serum triglycerides (TG), and low high density-lipoprotein cholesterol (HDL-C). Insulin resistance is considered to be the factor linking these different metabolic abnormalities [1]. MS may also indicate the presence of Cushing's syndrome (CS). Almost all patients with CS are obese or overweight, and have abdominal, visceral adiposity in about $95 \%$ of the patients. Many of the CS patients also have glucose metabolism abnormalities, impaired glucose tolerance or diabetes, hypertension, elevated TG levels and low HDL-C. Almost two thirds of CS patients fulfill at least three criteria for MS [2].

Similarities between the MS and CS, and reversibility of the features of CS, suggest that cortisol may contribute to the pathophysiology of both conditions. Emerging data suggest that patients with MS show hyperactivity of the hypothalamic-pituitary-adrenal (HPA) axis, which leads to a state of "functional hypercortisolism" $[3,4]$. This abnormality could be central in origin, due to hypersecretion of CRF or ACTH; alternatively, it could represent an adaptive phenomenon secondary to a state of functional cortisol resistance [5].

Android obesity in CS and in non CS abdominal obese with the MS, which is predominantly visceral, intra-abdominal, is more predictive of adipose-related comorbidities than gynecoid obesity, which has a relatively peripheral (gluteal) distribution $[6,7]$. Effective methods for assessing abdominal, visceral fat are important to investigate its role for the increased health risks in obesity [8]. For this reason the evaluation of body composition and body fat distribution (BFD) is clinically important. DXA is used to quantify abdominal fat mass and enables precise, accurate body composition and BFD assessment and it can be used in determination of COI values. The limitation of DXA derived body composition is that there are currently no universally accepted reference ranges for body composition based on DXA results. Also, to date CP values of COI have not been provided in order to precisely confirm abdominal obesity in CS and non CS obese [9].

The aim of this study was to develop a set of normative standards, reference ranges with determination of the CP values of DXA indexes of central, abdominal obesity as a ratio of android to gynoid fat and tissue mass and their percentages that best differentiate $\mathrm{CS}$ and $\mathrm{O}_{1}$ and confirm central abdominal obesity, and to determine their normal $\mathrm{CP}$ values that best differentiate group $\mathrm{C}$ from $\mathrm{CS}, \mathrm{O}_{1}$ and $\mathrm{O}_{2}$ and exclude abdominal obesity.

\section{MATERIAL AND METHODS}

This transversal study was organized and realized at the University Clinic of Endocrinology, Diabetes and Metabolic Disorders, Faculty of Medicine, "Ss Cyril and Methodius" University of Skopje. DXA assessment of body composition and BFD was performed in four groups of women, each consisting of 18 subjects: $1^{\text {st }}$ group of Cushing's syndrome (CS), with clinically confirmed CS with Body Mass Index (BMI) $(30.25 \pm 5.64$ $\left.\mathrm{kg} / \mathrm{m}^{2}\right)$ and age of $43.58 \pm 13.58$ years, $2^{\text {nd }}$ group of obese women $\mathrm{O}_{1}$, matched with CS according to their BMI $\left(29.8 \pm 4.08 \mathrm{~kg} / \mathrm{m}^{2}\right)$ and age $(40.4 \pm$ 12.05 years $), 3^{\text {rd }}$ group of obese women $\mathrm{O}_{2}$ with BMI $\left(35 \pm 1.2 \mathrm{~kg} / \mathrm{m}^{2}\right)$ and age of ( $45 \pm 8$ years), and the $4^{\text {th }}$ group $C$ of healthy women with normal BMI $\left(21.59 \pm 1.35 \mathrm{~kg} / \mathrm{m}^{2}\right)$ and age $(40.09 \pm 12.72$ years). All examined women were not different according to their age. BMI in $\mathrm{C}$ was significantly lower compared to $\mathrm{CS}, \mathrm{O}_{1}$ and $\mathrm{O}_{2}$. $\mathrm{BMI}$ was significantly lower in group $\mathrm{O}_{1}$ compared to $\mathrm{O}_{2}(\mathrm{p}<$ $0.0001)$. CS had not received any treatment at the time of the assessment and had typical signs and symptoms of CS including extreme central obesity. Anthropometric, DXA, hormonal and metabolic parameters confirmed CS diagnosis. Written informed consent was obtained from all patients before commencement of the study.

Body weight was measured to the nearest $0.1 \mathrm{~kg}$ using a calibrated digital weighing scale, with subjects minimally clothed in light-weight underwear. Standing height was measured to the nearest $0.1 \mathrm{~cm}$ with the shoes removed and the head in the Frankfort plane using a standard stadiometer. BMI was calculated as the patient's weight in kilograms divided by the height in meters squared.

DXA assessment in this study was performed with DXA System Lunar DPX-NT, which uses enCore Windows-XP Professional OS computer calibrated daily according to the standard procedures for maintenance and use as recommended by the manufacturer. For body composi- 
tion measurements the entire body of each subject was scanned. During DXA scan, subjects were positioned following the standard manufacturer's protocols in supine position, while the x-ray scanner performed a series of transverse scans, measured at $1-\mathrm{cm}$ intervals from the top of the head to the bottom of the toes. Android (A) and gynoid (G) region were automatically determined as defined by manufacturers instruction as well as $\mathrm{A}$ and $\mathrm{G}$ tissue and fat mass and their percenatages. Four indexes of central obesity were determined: central obesity index one ( $\left.\mathrm{COI}_{1}\right)$ as a ratio of $\mathrm{A}$ to $\mathrm{G}$ tissue mass $\mathrm{COI}_{1}=\mathrm{At} / \mathrm{Gt}$; $\mathrm{COI}_{2}$ as a ratio of $\mathrm{A}$ to $\mathrm{G}$ fat mass $\mathrm{COI}_{2}=\mathrm{Af} / \mathrm{Gf}, \mathrm{COI}_{3}$ as a ratio of $\mathrm{A}$ and $\mathrm{G}$ tissue $\%$ fat $\mathrm{COI}_{3}=\mathrm{At} \% / \mathrm{Gt} \%$ fat and $\mathrm{COI}_{4}$ as a ratio of $\mathrm{A}$ to $\mathrm{G}$ fat $\% \mathrm{COI}_{4}=\mathrm{Af} \% / \mathrm{Gf} \%$. CP values of DXA indexes of central, abdominal obesity $\mathrm{COI}_{1 \mathrm{~m}}, \mathrm{COI}_{2 \mathrm{~m}}, \mathrm{COI}_{3 \mathrm{~m}}$ and $\mathrm{COI}_{4 \mathrm{~m}}$ were determined to best differentiate $\mathrm{CS}$ with confirmed abdominal obesity from $\mathrm{O}_{1}$, healthy control women matched for age, menopausal status, and BMI. Also, CP values of DXA indexes of normal body composition and fat distribution $\mathrm{COI}_{1 \mathrm{n}}, \mathrm{COI}_{2 \mathrm{n}}, \mathrm{COI}_{3 \mathrm{n}}$ and $\mathrm{COI}_{4 \mathrm{n}}$ that best differentiate $\mathrm{CS}$ and $\mathrm{C}$ as well as $\mathrm{O}_{1}$ and $\mathrm{O}_{2}$ from $\mathrm{C}$ and exclude abdominal obesity were determined.

Cut-off point values were determined for all four DXA indexes and their sensitivity (S), specificity (SP), positive and negative predictive value (PPV and NPV) and diagnostic accuracy (DG) were evaluated in the following way:

- Sensitivity (true positive rate) is the probability that a test result - extreme visceral obesity will be positive when the disease CS is present.

- Specificity (true negative rate) is the probability that a test result will be negative; there is no extreme central body fat distribution when the disease is not present in $\mathrm{C}$ and $\mathrm{O}$.

- Positive predictive value (PPV): the proportion of those with a positive test result (extreme central body fat distribution) who actually have a disease (CS).
- Negative predictive value (NPV): the proportion of those with a negative test result (without extreme central obesity) who do not have a disease ( $\mathrm{C}$ and $\mathrm{O}$ ).

- Diagnostic accuracy (effectiveness) was expressed as a proportion of correctly classified subjects (true positive rate + true negative rate) among all subjects.

Statistical analyses were performed using statistical software program SPSS for Windows, version 19.0. Variables were presented as means \pm standard deviations (SD). P values $<0.05$ were considered to be statistically significant. For normally distributed variables, parametric tests were used for analysis. Differences among the groups were evaluated by performing an analysis of variance (ANOVA) for normally distributed parameters. Correlation coefficients were determined by Pearson's product moment.

\section{RESULTS}

COI indexes values determined during body composition assessment in total body scans, were highly significantly different among the 4 examined groups and they were highly significantly highest in CS and lowest in group C compared to all other groups $(\mathrm{p}<0.0001)$. COI 1 was significantly higher in $\mathrm{O}_{2}$ compared to $\mathrm{O}_{1}(\mathrm{p}<0.0001)$. $\mathrm{COI}_{2}$ was significantly higher in $\mathrm{O}_{2}$ compared to $\mathrm{O}_{1}(\mathrm{p}$ $<0.001)$ and it was highly significantly different between the other groups $(\mathrm{p}<0.0001)$. $\mathrm{COI}_{3}$ and $\mathrm{COI}_{4}$ were significantly higher in $\mathrm{O}_{2}$ compared to $\mathrm{O}_{1},(\mathrm{p}<0.017)$ and $(\mathrm{p}<0.018)$ respectively. $\mathrm{COI}_{1}$ and $\mathrm{COI}_{2}$ were significantly higher in $\mathrm{CS}$ compared to $\mathrm{O}_{1}(\mathrm{p}<0.0001)$. $\mathrm{COI}_{3}$ and $\mathrm{COI}_{4}$ were significantly higher in CS compared to $\mathrm{O}_{1},(\mathrm{p}<$ $0.009)$ and $(\mathrm{p}<0.007)$ respectively.

$\mathrm{COI}_{1}$ correlated highly significantly positively with $\mathrm{COI}_{2}$ as well as $\mathrm{COI}_{3}$ and $\mathrm{COI}_{4}$

Table 1. Significance of the difference between $\mathrm{COI}_{1}, \mathrm{COI}_{2}, \mathrm{COI}_{3}$ and $\mathrm{COI}_{4}$ values in $\mathrm{CS}, \mathrm{O}$ and $\mathrm{C}$

\begin{tabular}{|c|c|c|c|c|c|}
\hline Variable & CS & $\mathrm{O} 1$ & $\mathrm{O} 2$ & $\mathrm{C}$ & P-value \\
\hline $\mathrm{COI}_{1}$ & $0.68 \pm 0.09$ & $0.46 \pm 0.53$ & $0.55 \pm 0.06$ & $0.38 \pm 0.04$ & 0.0001 \\
\hline $\mathrm{COI}_{2}$ & $0.76 \pm 0.16$ & $0.42 \pm 0.09$ & $0.55 \pm 0.08$ & $0.25 \pm 0.07$ & 0.0001 \\
\hline $\mathrm{COI}_{3}$ & $1.07 \pm 0.15$ & $0.88 \pm 0.12$ & $0.99 \pm 0.07$ & $0.64 \pm 0.15$ & 0.0001 \\
\hline $\mathrm{COI}_{4}$ & $1.12 \pm 0.14$ & $0.91 \pm 0.12$ & $1 \pm 0.07$ & $0.65 \pm 0.15$ & 0.0001 \\
\hline $\begin{array}{l}\mathrm{CS}-\mathrm{Cush} \\
\mathrm{COI}_{1}=\mathrm{At} / \\
\mathrm{COI}_{2}=\mathrm{Af} / \\
\mathrm{COI}_{3}=\mathrm{At} \\
\mathrm{COI}_{4}=\mathrm{Af}^{2}\end{array}$ & $\begin{array}{l}\text { Syndrome; } \\
\text { droid/gynoi } \\
\text { hdroid/gynoi } \\
\text { fat (androi } \\
\text { o (android/g }\end{array}$ & $\begin{array}{l}\mathrm{O}-\mathrm{ob} \\
\text { nass ratio) } \\
\text { id tissue } \% \\
\text { fat } \% \text { ratio) }\end{array}$ & & ese & \\
\hline
\end{tabular}


between them $(\mathrm{p}<0.0001)$. $\mathrm{COI}_{2}$ values in all groups correlated highly significantly positively with $\mathrm{COI}_{1}, \mathrm{COI}_{3}$ and $\mathrm{COI}_{4}$ values $(\mathrm{p}<0.0001)$. $\mathrm{COI}_{1}$ values in group $\mathrm{O}_{2}$ and $\mathrm{C}$ correlated significantly positively with $\mathrm{COI}_{3}$ and $\mathrm{COI}_{4}$ values $(p<0.018 ; p<0.01)$, and also correlated positively in $\mathrm{C}(\mathrm{p}<0.01 ; \mathrm{p}<0.01)$. $\mathrm{COI}_{3}$ and $\mathrm{COI}_{4}$ did not correlate in groups $\mathrm{CS}$ and $\mathrm{O}_{1}(\mathrm{p}>0.05)$. BMI correlated highly significantly positively with all COI indexes $(\mathrm{p}<0.0001)$.

Cut off point values of COI indexes of central, abdominal obesity $\mathrm{COI}_{1 \mathrm{~m}}$ of 0.55 and the values of $\mathrm{COI}_{2 \mathrm{~m}}$ of $0.52, \mathrm{COI}_{3 \mathrm{~m}}$ of 0.9 and $\mathrm{COI}_{4 \mathrm{~m}}$ of 1.11 that best differentiated extreme central, abdominal, visceral body fat distribution in CS women from group $\mathrm{O}_{1}$ were determined. $\mathrm{COI}_{1 \mathrm{~m}}$ cut off point value of 0.55 best of all indexes differentiated $\mathrm{CS}$ and $\mathrm{O}_{1}$ for $\mathrm{S}, \mathrm{Sp}, \mathrm{PPV}, \mathrm{NPV}$ and DG for $100 \%$. $^{-C_{2}}, \mathrm{COI}_{3 \mathrm{~m}}$ and $\mathrm{COI}_{4 \mathrm{~m}}$ differentiated CS from $\mathrm{O}_{1}$ with $\mathrm{DG}$ of $94.44 \%, 70 \%$ and $80.56 \%$ respectively. Results shown in table 2 .

Table 2. S, SP, PPV, NPV and DG of COI ${ }_{l m}, \mathrm{COI}_{2 m^{\prime}}$ $\mathrm{COI}_{3 m}$ and $\mathrm{COI}_{4 m}$ cut-off point values in differentiation of $C S$ and $\stackrel{4 m}{O}$

\begin{tabular}{|c|c|c|c|c|}
\hline$\frac{\mathscr{\theta}}{\frac{0}{0}}$ & $\begin{array}{c}n \\
n \\
0 \\
\vdots \\
0^{0} \\
0\end{array}$ & 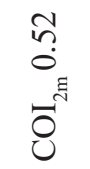 & $\begin{array}{l}\mathfrak{o}_{\tilde{E}} \\
\tilde{0}^{\mathrm{m}}\end{array}$ & 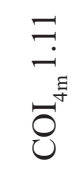 \\
\hline Sensitivity (\%) & 100 & 100 & 90 & 61.11 \\
\hline Specificity (\%) & 100 & 88.9 & 50 & 100 \\
\hline PPV (\%) & 100 & 90 & 64.29 & 100 \\
\hline NPV (\%) & 100 & 100 & 83.33 & 72 \\
\hline DG (\%) & 100 & 94.44 & 70 & 80.56 \\
\hline
\end{tabular}

Cut-off point values of DXA indexes of normal body composition and fat distribution $\mathrm{COI}_{1 \mathrm{n}}, \mathrm{COI}_{2 \mathrm{n}}, \mathrm{COI}_{3 \mathrm{n}}$ and $\mathrm{COI}_{4 \mathrm{n}}$ were determined. $\mathrm{COI}_{2 n}$ cut off point value of 0.38 best differentiated CS and C for S, Sp, PPV, NPV and DG for $100 \%$. COI $_{1 \mathrm{n}}$ value of 0.42 and $\mathrm{COI}_{4 \mathrm{n}}$ value of 0.9 differentiated CS and $\mathrm{C}$ for DG of $97.22 \%$. $\mathrm{COI}_{3 \mathrm{n}}$ value of 0.82 differentiated $\mathrm{CS}$ and $\mathrm{C}$ for $\mathrm{DG}$ of $92.86 \%$.

Cut off point value $\mathrm{COI}_{2 \mathrm{n}}$ of 0.38 best differentiated $\mathrm{C}$ and $\mathrm{O}_{2}$ for $\mathrm{S}, \mathrm{Sp}, \mathrm{PPV}, \mathrm{NPV}$ and $\mathrm{DG}$ for $100 \%$, but differentiated $\mathrm{C}$ from $\mathrm{O}_{1}$ with lower DG of 80.56. Also, cut off point value $\mathrm{COI}_{3}$ of 0.82 and $\mathrm{COI}_{4 \mathrm{n}}$ value of 0.9 differentiated $\mathrm{C}$ from $\mathrm{O}_{2}$ for $\mathrm{DG}$ of $94.44 \%$, but differentiated $\mathrm{C}$ from $\mathrm{O}_{1}$ with lower $\mathrm{DG}$ of $83.33 \%$ and $80.56 \%$ respectively. $\mathrm{COI}_{1 \mathrm{n}}$ of 0.42 differentiated $\mathrm{C}$ from $\mathrm{O}$, with DG of $91.67 \%$ but differentiated $\mathrm{C}$ from $\mathrm{O}_{1}$ for DG of $86.11 \%$.

\section{DISCUSSION}

Obesity is a complex and multifactorial chronic disease originating from a genetic and environmental or behavioral interchange, caused by an imbalance between energy intake and expenditure $[10,11]$. Obese subjects have higher percentage of fat mass from the total body mass compared to non obese and differ not only according to the degree of excess fat which they store, but also in the regional distribution of the fat within the body $[11,12]$. MS is associated with abdominal obesity, blood lipid disorders, inflammation, insulin resistance, full-blown di-

Table 3. S, SP, PPV, NPV and DG of COI ${ }_{1 n}, \mathrm{COI}_{2 n}, \mathrm{COI}_{3 n}$ and $\mathrm{COI}_{4 n}$ cut-off point values in differentiation of $C S$ and $C$

\begin{tabular}{|l|c|c|c|c|}
\hline & \multicolumn{4}{|c|}{$\mathrm{CS}-\mathrm{C}$} \\
\hline Variable & $\mathrm{COI}_{1 \mathrm{n}} 0.42$ & $\mathrm{COI}_{20} 0.38$ & $\mathrm{COI}_{3 \mathrm{n}} 0.82$ & $\mathrm{COI}_{4 \mathrm{n}} 0.9$ \\
\hline Sensitivity (\%) & 100 & 100 & 100 & 100 \\
\hline Specificity (\%) & 94.44 & 100 & 88.89 & 94.44 \\
\hline PPV (\%) & 94.74 & 100 & 83.33 & 94.44 \\
\hline NPV (\%) & 100 & 100 & 100 & 100 \\
\hline DG (\%) & 97.22 & 100 & 92.86 & 97.22 \\
\hline
\end{tabular}

Table 4. S, SP, PPV, NPV and DG of $\mathrm{COI}_{1 n^{\prime}} \mathrm{COI}_{2 n^{\prime}} \mathrm{COI}_{3 n}$ and $\mathrm{COI}_{4 n}$ cut-off point values in differentiation of $O$ and $O$, with $C$

\begin{tabular}{|c|c|c|c|c|c|c|c|c|}
\hline \multirow{2}{*}{ Variable } & \multicolumn{2}{|c|}{$\mathrm{COI}_{4} 0.42$} & \multicolumn{2}{|c|}{$\mathrm{COI}_{20} 0.38$} & \multicolumn{2}{|c|}{$\mathrm{COI}_{30} 0.82$} & \multicolumn{2}{|c|}{$\mathrm{COI}_{4} 0.9$} \\
\hline & $\mathrm{O}_{1}-\mathrm{C}$ & $\mathrm{O}_{2}-\mathrm{C}$ & $\mathrm{O}_{1}-\mathrm{C}$ & $\mathrm{O}_{2}-\mathrm{C}$ & $\mathrm{O}_{4}-\mathrm{C}$ & $\mathrm{O}_{2}-\mathrm{C}$ & $\mathrm{O},-\mathrm{C}$ & $\mathrm{O}_{2}-\mathrm{C}$ \\
\hline Sensitivity (\%) & 88.89 & 100 & 61.11 & 100 & 77.78 & 100 & 66.67 & 94.44 \\
\hline Specificity (\%) & 83.33 & 83.33 & 100 & 100 & 88.89 & 88.89 & 94.44 & $\overline{94.44}$ \\
\hline PPV (\%) & 84.21 & 85.71 & 100 & 100 & 87.5 & 90 & 92.31 & 94.44 \\
\hline NPV (\%) & 88.24 & 100 & 72 & 100 & 80 & 88.89 & $\overline{73.91}$ & 94.74 \\
\hline DG (\%) & 86.11 & 91.67 & 80.56 & 100 & 83.33 & 94.44 & 80.56 & $\overline{94.44}$ \\
\hline
\end{tabular}


abetes, and increased risk of developing cardiovascular disease, increased predisposition to cancers. CS have profound body composition changes, including increased central, visceral adiposity and decreased lean mass that is especially strongly linked to cardiovascular and metabolic risks [13]. Measurements of body composition and BFD have provided a research tool to study the metabolic effects of aging, obesity, and various diseases such as CS [14].

CS patients had a higher intra-abdominal fat area compared to obese subjects with the same anthropometric parameters, higher visceral to total and visceral to subcutaneous adipose tissue (AT) ratios on CT scan, especially in female CS. These data demonstrated that increased visceral BFD in both female and male patients with CS may increase the risk of the MS in that group of patients $[15,16,17]$. The impact of CS on whole and regional body composition and energy metabolism was assessed by DXA in Burt's study who showed that mean percentage fat mass was significantly greater by $30 \%$ in CS. Lean body mass was significantly lower by $15 \%$ in CS, and the proportion of lean tissue in the limbs was $12 \%$ less than normal [18]. Patients with CS had less than a twofold increase in subcutaneous fat and greater than a fivefold increase in intra-abdominal fat compared with values in healthy subjects. These findings suggested that fat in different body compartments responded differently to disease processes and that CT can be used to measure these changes. Effective treatment of hypercortisolism improved each of the five MS components and dramatically improved body composition abnormalities [19]. From the alterations in body composition observed after normalization of a hypercortisolic state, it was concluded that cortisol in CS directly or indirectly increased the total mass of AT and redistributed AT from peripheral to visceral depots as the same as body AT distribution in non CS obese before weight loss $[15,20]$. Body composition and fat distribution measured by DXA were evaluated in women with $\mathrm{CS}$ and were compared with healthy control women matched for age, menopausal status, and BMI and discovered that trunk fat mass percentage was significantly higher in CS and leg fat mass was not significantly different between the two groups [21, 22]. It is well established that the location of excess body fat is more important than the total quantity of adipose tissue when predicting the cardiometabolic consequences of obesity. There is growing evidence that intra-abdominal adipose tissue (IAAT), rather than total body fat, is a risk factor for metabolic conditions associated with obesity. For this reason the evaluation of IAAT is clinically important [22]. Accurate quantitative assessment of the visceral adiposity is essential in the evaluation of potential risk for the development of serious medical illnesses. As visceral obesity is associated with poor prognosis, metabolic disturbances and degree of pathology in several chronic diseases, it is of great importance to identify methods that quantify AT accurately and can specifically depict visceral from total adipose tissue. Effective methods for assessing visceral fat are important to investigate the role of visceral fat for the increased health risks in obesity $[9,23]$. At present, reliable imaging techniques for measuring visceral, abdominal adiposity include magnetic resonance imaging (MRI) and computed tomography (CT), which directly measure IAAT, allowing for quantification of several fat depots. CT may give better discrimination between fat and other tissues but MRI has the advantage that it does not expose subjects to ionising radiation. However, both methods are costly, time-consuming, inconvenient to apply, and often unavailable for clinical and research purposes [16, 17, 22].

DXA method is the gold standard for assessment of bone health and body composition that provides accurate, comprehensive, precise measurements of total body fat percentage, along with segmental BFD in regions such as arms, legs, android (waist) and gynoid (hips) [24,25]. DXA measures three of the principal components of the body: fat mass, lean soft-tissue mass, and the bone mineral content $[26,27,28]$. Physicians today use DXA for body composition assessment because it accurately shows exactly where fat is distributed throughout the body. DXA, which has emerged as a method for assessing regional and whole body soft tissue composition is less invasive, less expensive and more accessible than $\mathrm{CT}$, and involves only minimal exposure to ionizing radiation $[6,27,29]$. Agreement between DXA and whole-body CT fat mass has been found to be very high as well with correlations of 0.99 . Measurement of IAAF by MRI, was highly correlated to the central abdominal fat measured by DXA [29]. In obese women, it was found that DXA could predict IAAT [21, 25 ] and the $\mathrm{V} / \mathrm{S}$ tissue ratio may provide a better index of the cardiometabolic impact of body fat 
composition than absolute quantification of each deposit independently [30, 31].

The necessity for precise and clinically expedient measures for quantifying visceral AT is evident. However, it is also essential to develop quantitative criteria for defining visceral obesity relative to the metabolic disturbances, and it is important to establish diagnostic CP for normal and abnormal values. To date, these criteria have not been clearly defined in any modality $[9,30]$. There is no consensus in the literature for a diagnostic CP for visceral obesity that would indicate increased cardiovascular risk; this is partially because of limitations in performing CT scans on a large scale. Also, there are no diagnostic CP for abdominal, visceral obesity for DXA relations of central to peripheral body fat compartments. DXA is "gold standard" that can help improvement of equations for more accurate clinical assessment of lean and fat body mass [29, 30, 32, 33]. DXA continues to be used as the reference standard for whole body composition analysis in research studies. A single DXA measure, especially of fat mass and its percentage in different body regions would not be used in the medical management of the patients, particularly in MS and all consecutive complications.

The intention of this study was to discover normal and abnormal body composition with DXA indexes of the relationships of the changed different body compartments characteristic for the MS. Reference values of some DXA indexes for normal and pathologic body composition are needed to be performed that will be useful for all populations of patients at different ages.

Shubeska [6] evaluated the differences of the body composition and BFD as measured by DXA in women with CS with confirmed extreme abdominal, visceral obesity in comparison with healthy obese control women matched for age, menopausal status, and BMI [34, 35]. It was discovered that total and regional fat mass, tissue mass, lean body mass values did not differentiate $\mathrm{CS}$ and $\mathrm{O}$ significantly and concluded that determination of the relationships of their regional values had to be done. It was shown with DXA scans of the entire body that the ratios of the not significantly different central (abdominal) and peripheral regional parts of the body, significantly and precisely differentiated the patients with $\mathrm{CS}$ and non CS obese, and confirmed extreme central BFD in CS. DXA enabled determination of BFD as well as central obesity index, which is an indicator of central, abdominal obesity, and was calculated as a ratio of $A$ to $G$ tissue percent fat. The objective of this study was to develop prediction equations for estimating visceral adiposity measured by DXA and to establish CP values to define visceral adiposity as well as normal BFD. Four indexes of central obesity $\mathrm{COI}_{1}$. were determined in order to best differentiate ${ }^{4} \mathrm{CS}$ and $\mathrm{O}_{1}$ and to confirm visceral, abdominal obesity in CS and also to best differentiate CS and $\mathrm{C}$ as well as $\mathrm{O}_{1}$ and $\mathrm{O}_{2}$ from $\mathrm{C}$ in order to discover normal body fat distribution in $\mathrm{C}$ and exclude abdominal obesity. $\mathrm{COI}_{1-4}$ values were highly significantly different among the 4 groups and were significantly highest in CS patients, confirming extreme visceral obesity in CS and were lowest in group $\mathrm{C}$ indicating normal BFD.

Highly significantly higher values of COI and $\mathrm{COI}_{2}$ and their percentage ratios $\mathrm{COI}_{3}$ and $\mathrm{COI}_{4}$ in $\mathrm{CS}$ compared to $\mathrm{O}_{1}$ and $\mathrm{O}_{2}$ as well as $\mathrm{C}$ indicated predomination of android to gyoid tissue and fat mass and their percentages from the total tissue and fat mass in CS. Also, significantly higher values of these DXA indexes in group $\mathrm{O}_{2}$ with significantly higher $\mathrm{BMI}$ compared to group $\mathrm{O}_{1}$ that was matched with CS with their $\mathrm{BMI}$ and age, indicated positive association between BMI increase and central, abdominal visceral BFD. Significantly positive correlation among $\mathrm{COI}_{1}$ and $\mathrm{COI}_{2}$ as well as $\mathrm{COI}_{3}$ and $\mathrm{COI}_{4}$ showed that tissue mass increase was associated with fat mass increase as well as their percentages from the total body mass. Also, BMI highly significantly positive correlation with all $\mathrm{COI}$ in a group of non $\mathrm{CS}$ women $\left(\mathrm{C}, \mathrm{O}_{1}\right.$ and $\mathrm{O}_{2}$ ) confirmed that BMI increase is associated with increase of indexes of abdominal, visceral obesity indicating increased abdominal BFD. BMI correlation with COI also confirmed BMI increase positive association with BFD increase. Shubeska in 2009 discovered with DXA that BMI increase in healthy women was associated with a more pronounced abdominal BFD, associated with higher obesity degree [36], indicating substantially higher risk for development of metabolic and cardiovascular complications especially in postmenopausal women $[20,21,26$, $34,35,37]$.

$\mathrm{CP}$ values of DXA indexes of central, abdominal obesity $\mathrm{COI}_{1 \mathrm{~m}}$ of $0.55, \mathrm{COI}_{2 \mathrm{~m}}$ of 0.52 , $\mathrm{COI}_{3 \mathrm{~m}}$ of 0.9 and $\mathrm{COI}_{4 \mathrm{~m}}$ of 1.11 differentiated with highest DG extreme central, abdominal, visceral body fat distribution in CS women in 
comparison to group $\mathrm{O}_{1}$ and they also could be used in discovering central, abdominal body fat distribution in non CS obese women with MS that are associated with increased risk of MS complications. $\mathrm{COI}_{1 \mathrm{~m}}$ cut off point value of 0.55 best differentiated $\mathrm{CS}$ and $\mathrm{O}_{1}$ with highest $\mathrm{DG}$ of $100 \%$. CP values of DXA indexes of normal body composition and BFD $\mathrm{COI}_{1 \mathrm{n}-4 \mathrm{n}}$, differentiated with highest DG CS from group $\mathrm{C}$ with normal BMI and normal BFD. $\mathrm{COI}_{2 \mathrm{n}}$ cut off point value of 0.38 best differentiated $\mathrm{CS}$ and $\mathrm{C}$ for highest DG of $100 \%$. CP values of DXA indexes of normal body composition and BFD COI ${ }_{4 n}$ were determined that best differentiated with highest $\mathrm{DG}$ group $\mathrm{C}$ from group $\mathrm{O}_{1}$ and $\mathrm{O}_{2}$ with significantly higher BMI than group $\mathrm{C}$. $\mathrm{COI}_{2 \mathrm{n}}$ cut off point value of 0.38 , differentiated $\mathrm{C}$ from $\mathrm{O}_{2}$ for DG of $100 \%$. CP values of DXA indexes of normal body composition and BFD COI ${ }_{1 n-4 n}$ differentiated $\mathrm{C}$ and $\mathrm{O}_{2}$ with higher DG compared to $\mathrm{O}_{1}$ as a result of a significantly higher BMI in $\mathrm{O}_{2}$ compared to $\mathrm{O}_{1}$ and they enabled more precise distinction of normal $\mathrm{COI}_{\mathrm{n}}$ values.

\section{CONCLUSION}

This study discovered DXA diagnostic criteria of visceral, abdominal obesity and normal body composition and body fat distribution. COI indexes ratios values of central to peripheral parts of the body, android to gynoid tissue and fat mass and their percentages $\mathrm{COI}_{1 \mathrm{~m}} \mathrm{CP}$ value of 0.55 and $\mathrm{COI}_{2 \mathrm{~m}}$ value of 0.52 were discovered as DXA diagnostic indexes of visceral, abdominal obesity that best differentiated CS from group $\mathrm{O}_{1}$ as a consequence of the hyrepercortisolism that enabled significant differentiation between the two groups.

COI indexes ratios were significantly lowest in group $\mathrm{C}$ compared to all other groups, showing normal and excluding abdominal BFD. Cut-off point values of DXA indexes of normal body composition and BFD $\mathrm{COI}_{1 \mathrm{n}-4 \mathrm{n}}$, differentiated with high DG CS from group $\mathrm{C}$, but $\mathrm{COI}_{2 \mathrm{n}}$ cut off point value of 0.38 differentiated them with the highest DG of $100 \%$ and it can be used as the best DXA diagnostic index of normal body composition and BFD. That was also confirmed in the differentiation of groups $\mathrm{C}$ and $\mathrm{O}_{2}$. CP values of DXA indexes of normal body composition and $\mathrm{BFD} \mathrm{COI}_{1 \mathrm{n}-4 \mathrm{n}}$ differentiated group $\mathrm{C}$ and $\mathrm{O}_{2}$ compared to $\mathrm{O}_{1}$ with higher $\mathrm{DG}$. Significantly higher BMI values in $\mathrm{O}_{2}$ compared to $\mathrm{O}_{1}$ associated with significantly higher $\mathrm{COI}_{1 \mathrm{n} \text { - }}$ indexes values confirmed the association of higher degree of obesity with more central, abdominal, visceral BFD in obese women that was also confirmed with highly significantly positive correlation of BMI with all COI indexes in a non $\mathrm{CS}$ group consisted of groups $\mathrm{C}, \mathrm{O}_{1}$ and $\mathrm{O}_{2}$. $\mathrm{CP}$ value of DXA index of normal body composition and $\mathrm{BFD} \mathrm{COI}_{2 \mathrm{n}}$ of 0.38 differentiated group $\mathrm{C}$ from $\mathrm{O}_{2}$ for $\mathrm{DG}$ of $100 \%$ and it was confirmed that it could be used as diagnostic criterion of normal BFD.

Determination of DXA COI indexes CP values of abdominal, visceral obesity is very important to discover obese women with visceral obesity, which is the main characteristic of the MS that is associated with higher cardiometabolic risks and increased risk of other MS complications. It can be concluded that DXA COI indexes were confirmed as useful diagnostic parameters in discovering abdominal BFD and they could be used as useful diagnostic criteria of the MS.

\section{REFERENCES}

1. Meigs JB, Wilson PW, Fox CS, et al. Body mass index, metabolic syndrome, and risk of type 2 diabetes or cardiovascular disease. J Clin Endocrinol Metab 2006; 91: 2906-2912.

2. Chanson P, Salenave S. Metabolic Syndrome in Cushing's Syndrome. Neuroendocrinology 2010; 92(suppl 1): 96-101.

3. Anagnostis P, Athyros VG, Tziomalos K, et al. Clinical Review: The pathogenetic role of cortisol in the metabolic syndrome: a hypothesis. J Clin Endocrinol Metab 2009 Aug; 94(8): 2692-701.

4. Walker BR. Cortisol--cause and Cure for Metabolic Syndrome? Diabet Med 2006 Dec; 23(12): 1281-8.

5. Pasquali R, Cantobelli S, Casimirri F, et al. The hypothalamic-pituitary-adrenal axis in obese women with different patterns of body fat distribution. $\mathrm{J}$ Clin Endocrinol Metab 1993 Aug; 77(2): 341-6.

6. Shubeska Stratrova S, Dimitrovski C, Todorovska L, et al. Evaluation of the body composition in female Cushings. J Anthropol Soc Serbia (Novi Sad) 2008; 43: 440-447.

7. Neeland IJ, Turer AT, Ayers CR, et al. Body fat distribution and incident cardiovascular disease in obese adults. J Am Coll Cardiol 2015 May; 65(19): 2150-2151. 
8. Borga M, West J, Bell JD, et al. Advanced body composition assessment: from body mass index to body composition profiling. J Investig Med 2018 Jun; 66(5): 1-9.

9. Neeland IJ, Grundy SM, Li X, et al. Comparison of visceral fat mass measurement by dual-X-ray absorptiometry and magnetic resonance imaging in a multiethnic cohort: the Dallas Heart Study. Nutr Diabetes 2016 Jul; 6(7): e221.

10. Müller MJ, Geisler C. Defining obesity as a disease. Eur J Clin Nutr 2017; 71: 1256-1258.

11. Bray GA, Kim KK, Wilding JPH. Obesity: a chronic relapsing progressive disease process. A position statement of the World Obesity Federation. Obes Rev 2017 Jul; 18(7): 715-723.

12. Sharma AM, Campbell-Scherer DL. Redefining obesity: beyond the numbers. Obesity (Silver Spring) 2017 Apr; 25(4): 660-661.

13. Maggi S, Busetto L, Noale M et al. (2015). Obesity: Definition and epidemiology. In A. Lenzi, S. Migliaccio, \& L. M. Donini (Eds.), Multidisciplinary approach to obesity: From assessment to treatment. Cham, Switzerland: Springer International Publishing, 31-39.

14. Shuster A, Patlas M, Pinthus JH et al. The clinical importance of visceral adiposity: a critical review of methods for visceral adipose tissue analysis. $\mathrm{Br}$ J Radiol 2012 Jan; 85(1009): 1-10.

15. Rockall AG, Sohaib SA, Evans D, et al. Computed tomography assessment of fat distribution in male and female patients with Cushing's syndrome. Eur J Endocrinol 2003 Dec; 149(6): 561-7.

16. Laddu DR, Lee VR, Blew RM, et al. Predicting visceral adipose tissue by MRI using DXA and anthropometry in adolescents and young adults. Int $\mathbf{J}$ Body Compos Res 2012; 10(4): 93-100.

17. Geer EB, Shen W, Gallagher D, et al. MRI assessment of lean and adipose tissue distribution in female patients with Cushing's disease. Clin Endocrinol (Oxf) October 2010; 73(4): 469-475.

18. Burt MG, Gibney J, Ho KKY. Characterization of the metabolic phenotypes of Cushing's syndrome and growth hormone deficiency: a study of body composition and energy metabolism. Clin Endocrinol (Oxf) Apr 2006; 64(4): 436-443.

19. Geer EB, Shen W, Strohmayer E, et al. Body composition and cardiovascular risk markers after remission of Cushing's Disease: A prospective study using whole-body MRI. J Clin Endocrinol Metab 2012; 97: 1702-1711.

20. Shubeska Stratrova S, Kostova E, Janicevic Ivanovska $\mathrm{D}$, et al. Body fat distribution changes during weight loss determined by DXA android/ gynoid indexes of abdominal obesity. Physioacta 2019; 33(2): 9-18.

21. Snijder MB, Visser M, Dekker JM, et al. The prediction of visceral fat by dual-energy X-ray absorptiometry in the elderly: a comparison with computed tomography and anthropometry. Int $\mathrm{J}$ Obes Relat Metab Disord 2002 Jul; 26(7): 984-93.

22. Garrapa GG, Pantanetti P, Arnaldi G, et al. Body composition and metabolic features in women with adrenal incidentaloma or Cushing's Syndrome. J Clin Endocrinol Metab. 2001; 86(11): 5301-5306.

23. Ribeiro-Filho FF, Faria AN, Azjen S, et al. Methods of estimation of visceral fat: advantages of ultrasonography. Obes Res December 2003 Dec; 11(12): 1488-1494.

24. Choi YJ, Seo YK, Lee EJ, Chung YS. Quantification of visceral fat using dual-energy $\mathrm{x}$-ray absorptiometry and its reliability according to the amount of visceral fat in Korean adults. J Clin Densitom 2015 Apr-Jun; 18(2): 192-7.

25. Salamone LM, Fuerst T, Visser M. Measurement of fat mass using DEXA: a validation study in elderly adults. J Appl Physiol 2000; 89(1): 345-52.

26. Brownbill RA, Ilich JZ. Measuring body composition in overweight individuals by dual energy x-ray absorptiometry. BMC Med Imaging 2005; 5: 1 .

27. Measurement of soft tissue composition by dual energy X-ray absorptiometry. Br J Nutrit 1997; 77(2): 151-163.

28. Denton N, Karpe F. Measuring body composition and regional fat mass accurately. Practical diabetes 2016; 33(7): 224-226.

29. Kullberg J, Brandberg J, Angelhed JE, et al. Whole-body adipose tissue analysis: comparison of MRI, CT and dual energy X-ray absorptiometry. Br J Radiol 2009 Feb; 82(974): 123-30.

30. Ladeiras-Lopes R, Sampaio F, Bettencourt N, et al. The ratio between visceral and subcutaneous abdominal fat assessed by computed tomography is an independent predictor of mortality and cardiac events. Rev Esp Cardiol (Engl Ed) 2017 May; 70(5): 331-337.

31. Lopes HF, Correa-Giannella ML, Consolim-Colombo FM, et al. Viseral adiposity syndrome. Diabetol Metab Syndr 2016; 8(40): B4-B12.

32. Ibrahim Q, Ahsan M. Measurement of Visceral Fat, Abdominal Circumference and Waist-hip Ratio to Predict Health Risk in Males and Females. Pakistan J Biol Sci 2019; 22: 168-173.

33. Hunter HL, Nagy TR. Body composition in a seasonal model of obesity: longitudinal measures and validation of DXA. Obes Res 2002 Nov; 10(11): 1180-1187.

34. Shubeska-Stratrova S. Densitometric to anthropometric indexes of visceral obesity relations. J Anthropol Society of Serbia (Novi Sad) 2011; 46: 49-58.

35. Shubeska-Stratrova S. Dual-energy x-ray absorptiometry assessment of the body composition and 
body fat distribution in pre- and postmenopausal women. J Anthropol Soc Serbia (Novi Sad) 2010; 45: 199-206.

36. Shubeska Startrova S. Dual-energy x-ray absorptiometry assessment of the body composition in obese women. J Anthropol Soc Serbia (Novi Sad) 2009; 44: 455-461.

37. Kim JS, Yoo SM, Kim KN, et al. Comparison of DXA and CT for truncal obesity in adult women related to metabolic complications. J Korean Acad Fam Med 2007 Sep; 28(9): 675-681.

\title{
Резиме
}

\section{ПРЕСЕЧНИ ТОЧКИ НА ДИЈАГНОСТИЧКИ ИНДЕКСИ НА ЦЕНТРАЛНА ДЕБЕЛИНА ОДРЕДЕНИ СО АПСОРПЦИОМЕТРИЈА СО ДВОЈНОЕНЕРГЕТСКИ Х-ЗРАЦИ КАЈ КУШИНЗИ И КАЈ ДЕБЕЛИ ЖЕНИ}

\section{Славица Шубеска Стратрова ${ }^{1}$, Саша Јовановска Мишевска ${ }^{1}$, Искра Битоска $^{1}$, Ирена Кафеџиска ${ }^{2}$}

\begin{abstract}
${ }^{1}$ Универзитетска клиника за ендокринологија, дијабетес и метаболички нарушувања, Медицински факултет, Универзитет „Св. Кирил и Методиј“, Скопје, РС Македонија

2 Универзитетска клиника за ревматологија, Медицински факултет, Универзитет „Св. Кирил и Методиј“, Скопје, РС Македонија
\end{abstract}

Цел: Целта на оваа студија беше да се развијат квантитативни критериуми за дефинирање на висцерална дебелина и да се воспостават, со абсорпциометрија со двојноенергетски X-зраци (DXA,) дијагностички пресечни точки (CP) на нормалните и на абнормалните вредности на индексите на централна дебелина (COI), кои најдобро ја диференцираат екстремната висцерална дебелина кај Кушинговиот синдром (CS) од жени што се дебели без CS и недебели жени.

Материјал и методи: Вредностите на $\mathrm{COI}_{1-4}$ пресметани како однос на андроидната и гиноидната ткивна маса, масна маса и нивните \% беа одредени во 4 групи, секоја составена од 18 жени: прва група CS; втора група дебели жени $\left(\mathrm{O}_{1}\right)$, кои не се разликуваа според нивната возраст и ВMI co CS; трета група дебели жени $\left(\mathrm{O}_{2}\right)$ co BMI $35 \pm 1,2 \mathrm{~kg}$ и четврта група на недебели здрави жени (C) со нормален BMI. Дијагностичката точност (DG) беше одредена на пресечните точки (CP) на $\mathrm{COI}_{1 \mathrm{~m}-4 \mathrm{~m}}$ индексите на абдоминалната дебелина и на $\mathrm{COI}_{1 \mathrm{n}-4 \mathrm{n}}$ индексите на нормална телесна масна дистрибуција (BFD).

Резултати: Вредностите на индексите $\mathrm{COI}_{1-4}$ беа високо сигнификантно различни меѓу четирите испитани групи и беа сигнификантно највисоки кај пациенти co CS и најниски во групата C. $\mathrm{COI}_{1 \mathrm{~m}-4 \mathrm{~m}} \mathrm{CP}$ вредностите ја диференцираа екстремната висцерална, абдоминална дебелина кај CS со највисока DG, исто како и $\mathrm{COI}_{1 \mathrm{n}-4 \mathrm{n}}$ CР вредностите, кои ја диференцираа нормалната BFD од групата C. $\mathrm{COI}_{1 \mathrm{~m}}$ CР од 0,55 најдобро ги диференцираше $\mathrm{CS}$ од $\mathrm{O}_{1}$ за DG од $100 \%$. $\mathrm{COI}_{2 \mathrm{n}}$ од 0,38 најдобро ги диференцираше С од CS и $\mathrm{O}_{2}$ за најголема DG од $100 \%$ во споредба со О поради значително повисоките вредности на ВMI и $\mathrm{COI}_{1 \mathrm{n}-4 \mathrm{n}}$ во $\mathrm{O}_{2}$, кои беа поврзани со поизразена абдоминална дебелина и високо сигнификантна позитивна корелација со BMI.

Заклучок: Вредностите на DXA-пресечните точки на индексите $\mathrm{COI}_{1 \mathrm{~m}-4 \mathrm{~m}}$ и $\mathrm{COI}_{1 \mathrm{n}-4 \mathrm{n}}$ беа утврдени како дијагностички индекси и критериуми корисни за откривање на екстремно абдоминална и нормална BFD. COI ${ }_{1 \mathrm{~m}}$ СР вредноста од 0,55 беше докажана како дијагностички критериум на екстремна абдоминална дебелина и $\mathrm{COI}_{2 n}$ од 0,38 како дијагностички критериум на нормална BFD што ја исклучи абдоминалната дебелина. Другите вредности на СР на индексите $\mathrm{COI}_{1 \mathrm{~m}-4 \mathrm{~m}}$ и COI ${ }_{1 \mathrm{n}-4 \mathrm{n}}$ исто така имаа висока DG во откривање на абдоминалната и нормалната телесна дистрибуција на масти.

Клучни зборови: DXA, абдоминална дебелина, индекси на централна дебелина, пресечни точки 